TABLE II-Percentage efficiency relative to day 8 (Saturday)

\begin{tabular}{|c|c|c|c|c|}
\hline & & \multicolumn{2}{|c|}{ Monday } & \multirow{2}{*}{ Tuesday } \\
\hline & & 1600 & 2000 & \\
\hline \multicolumn{5}{|c|}{ Logical reasoning } \\
\hline $\begin{array}{l}\text { Fentanyl } \quad . \\
\text { Halothane } \quad \ldots \\
\text { Advantage of halothane }\end{array}$ & $\begin{array}{l}\cdots \\
\cdots\end{array}$ & $\begin{aligned} & 34 \cdot 6^{* * *} \\
& 19 \cdot 5 * * * \\
&-15 \cdot 1\end{aligned}$ & $\begin{array}{l}68 \cdot 1^{* * *} \\
88 \cdot 3^{*} \\
20 \cdot 2^{* *}\end{array}$ & $\begin{array}{l}89 \cdot 3^{* *} \\
93 \cdot 0^{*} \\
3 \cdot 7\end{array}$ \\
\hline \multicolumn{5}{|c|}{ Calculation } \\
\hline $\begin{array}{l}\text { Fentanyl } \quad . \\
\text { Halothane } \quad \ldots \\
\text { Advantage of halothane }\end{array}$ & $\begin{array}{l}\cdots \\
\cdots \\
\cdots\end{array}$ & $\begin{aligned} & 27 \cdot 8^{* * *} \\
& 15 \cdot 7 * * * \\
&-12 \cdot 1\end{aligned}$ & $\begin{array}{l}58 \cdot 2^{* * *} \\
79 \cdot 6 \\
21 \cdot 4^{*}\end{array}$ & $\begin{array}{l}92 \cdot 1^{* * *} \\
93 \cdot 7^{*} \\
1 \cdot 8\end{array}$ \\
\hline \multicolumn{5}{|c|}{ Cancellation } \\
\hline $\begin{array}{l}\text { Fentanyl } \quad \ldots \\
\text { Halothane } \quad . \\
\text { Advantage of halothane }\end{array}$ & $\begin{array}{l}\cdots \\
\cdots\end{array}$ & $\begin{array}{c}36 \cdot 2 * * * \\
8 \cdot 9^{* * *} \\
-27 \cdot 3^{* *}\end{array}$ & $\begin{array}{l}73 \cdot 0^{* * *+} \\
95 \cdot 4 \\
22 \cdot 4^{*}\end{array}$ & $\begin{array}{l}94 \cdot 4^{\dagger} \\
97 \cdot 5 \\
8 \cdot 3\end{array}$ \\
\hline
\end{tabular}

†This figure is based on the results in 16 patients because two were unable to do the test because of diplopia.

†This figure is based on the results in 17 patients because one was unable to do the test because of diplopia.

Significance of $(a)$ in first two rows, disruption from 100 "., efficiency; and $(b)$ in third row, difference in disruption between the two types of anaesthesia.

$* \mathrm{P}<0.05$

$\left.\begin{array}{l}* * \mathrm{P}<0.01 \\ * * * \mathrm{P}<0.001\end{array}\right\}$ on 1 -tailed $t$ test (either related or independent).

Finally, it might be argued that premedication with papaveretum $20 \mathrm{mg}$ and hyoscine $0.4 \mathrm{mg}$ does not actually form part of a day-care anaesthetic and could have affected the patient's alertness. Comparison was possible between six patients who were given $15 \mathrm{mg}$ or $20 \mathrm{mg}$ papaveretum during the afternoon of the day of operation and those receiving no further analgesia. There was no evidence in the performance scores at 1600 or 2000 that the patients receiving papaveretum after operation were more disrupted than the rest. It therefore seems unlikely that the premedication contributed to the performance results reported.

\section{Discussion}

The curves of recovery in performance efficiency were similar for the three tasks used in this trial and they were pooled to give a global index of recovery. At first there was an advantage for the fentanyl group in that they awoke earlier, but after six hours the halothane patients were equal to them in preformance and from that point became better. At 2000 on the day of operation the advantage of halothane anaesthesia was significant for all three tasks. All the tests used were short and did not examine ability to sustain attention over a prolonged period, but, clearly, this should not be required of a patient on the day of surgery.

The question arises over what is an acceptable level of performance efficiency for discharging a patient, and here the evidence has to be indirect. Under relatively common adverse conditions people are often at about $90^{\circ}$ o of their normal efficiency; $80 \mathrm{mg}$ of alcohol per $100 \mathrm{ml}$ blood, the current legal limit, reduced steering efficiency on a simulated driving task to $89^{\circ}{ }^{\circ}$, , while normal doses of psychotropic drugs caused efficiency on complex psychomotor tasks to fall to not less than $90^{\circ},{ }^{\circ}{ }^{6}$ Limiting the duration of sleep to three hours reduced efficiency to $90^{\circ}{ }_{0}$ on a similar calculation task to the one used here. ' No sleep at all the previous night reduced efficiency to $60^{\circ}{ }_{0}$. This would suggest that $60-90^{\prime \prime}{ }_{11}$ recovery would be acceptable, and this would imply a seven to nine hour stay in hospital.

In deciding whether this could be a general rule the considerable variation in performance efficiency between individuals needs to be remembered. On the $60^{\circ}{ }_{0}$, performance efficiency criterion all 12 patients receiving halothane would have gone home at 2000, but six of the 19 receiving fentanyl would have been unfit. Unfortunately the tests described here are unsuitable for use in clinical practice because a performance ability baseline has to be established for each individual. Also more goes into the decision to discharge the patient than just the level of intellectual recovery. Nevertheless, this study emphasises again the importance of support and help at home when planning day-care surgery for the individual.

\section{References}

1 Ruckley, C V, et al, Lancet, 1973, 2, 1193.

2 Green, R, et al, Anaesthesia, 1963, 18, 189.

3 Dixon, R A, and Thornton, J A, British fournal of Anaesthesia, 1973, 45, 207.

- Folkard, S, British fournal of Psychology, 1975, 66, 1.

5 Drew, G C, Colquhoun, W P, and Long, H A, Medical Research Council Memorandum, No 38. London, HMSO, 1959.

${ }^{6}$ Klein, K E, Aerospace Medicine, 1972, 43, 1207.

7 Wilkinson, R T, Edwards, R S, and Haines, E, Psychonomic Science, 1966 , 5, 471 .
Departments of Paediatrics and Pathology, Newcastle General Hospital, Newcastle upon Tyne NE4 6BE

C R PULLAN, MB, MRCP, registrar in paediatrics

$T C$ NOBLE, FRCP, DCH, consultant paediatrician

D J SCOTT, MB, MRCPATH, consultant paediatric pathologist

$\mathrm{K}$ WISNIEWSKI, MD, senior registrar in paediatric neurology

Department of Virology, Royal Victoria Infirmary, Newcastle upon Tyne NE1 4LP

P S GARDNER, MD, DIPBACT, professor of clinical virology aemic remission on immunosuppressive treatment, were seen recently. The clinical syndromes were variable and atypical and the antibody responses unpredictable. Conventional doses of pooled immunoglobulin failed to protect the two children to whom it was given. Degeneration rather than inflammation seems to characterise the encephalopathy in immunosuppressed children infected with measles virus.

\section{Introduction}

The dangers of viral, bacterial, fungal, and protozoal infections in immunosuppressed hosts have recently been summarised ${ }^{1}$ comprehensively, but relatively few examples of fatal or lifethreatening illness due to measles infection have been recorded in such patients. ${ }^{2-4}$ During the past six months there have been two cases of measles encephalopathy and one of giant-cell 
pneumonia in a small series of 20 children being treated for leukaemia at Newcastle General Hospital. We suspect that such atypical measles infections as we describe may not always be recognised because of their unusual clinical picture, their inconsistent antibody response, and, in those with encephalopathy, the patchy and degenerative nature of the lesions in the brains of fatal cases. Conventional protective doses of pooled immunoglobulin failed to prevent measles infection in the two children to whom it was given.

\section{Case 1}

This child, born in 1970, developed giant-cell pneumonia. She was first admitted with acute lymphoblastic leukaemia in February 1975 and was treated with cytotoxic drugs on the American Leukaemia Group B 6801 schedule. She made good progress until the 11th week of treatment, when she was exposed to measles infection. Three days later she was given pooled immunoglobulin in a dose of $750 \mathrm{mg}$ ( $45 \mathrm{mg} / \mathrm{kg}$ body weight), but 23 days after the contact she developed a florid measles rash that persisted for two weeks and latterly became haemorrhagic. She reached hospital on the sixth day of the rash, by which time her temperature was $39.5^{\circ} \mathrm{C}$ and she had signs of bronchopneumonia. All cytotoxic treatment was stopped. Twelve days after the appearance of the rash she was first examined for measles virus, which was cultured from her nasopharyngeal secretions. Measles antigen was also shown in cells from these secretions by immunofluorescence, and many giant cells were seen loaded with virus antigen (fig 1). At this stage the complement-fixing antibody titre to measles was less than $1 / 4$. Since her clinical condition was deteriorating

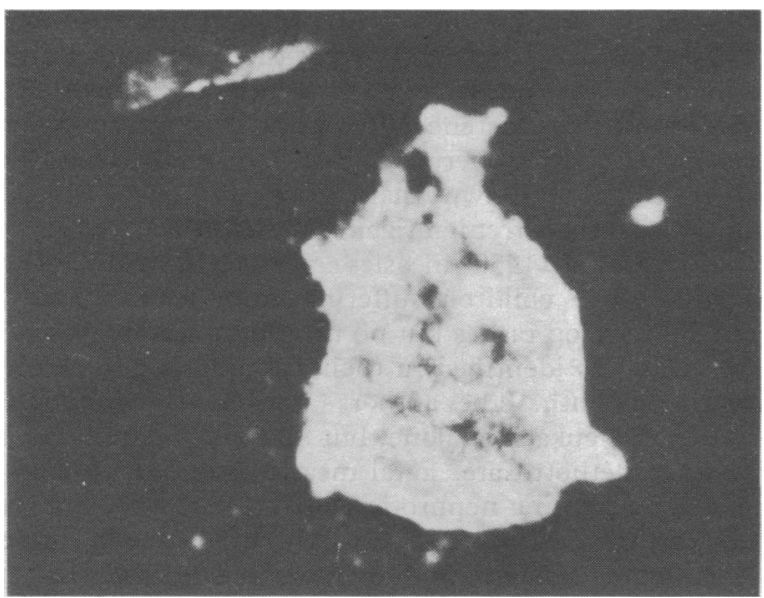

FIG 1-Immunofluorescence of measles antigen in giant cell from nasopharyngeal secretions. ( $\times 1500$.

and her $x$-ray films persistently showed diffuse micronodular shadowing she was given injections of pooled immunoglobulin $1500 \mathrm{mg}$ $(90 \mathrm{mg} / \mathrm{kg})$ on the $14 \mathrm{th}, 15 \mathrm{th}$, and 16th days after the appearance of the rash, but virus was still easily identified by fluorescence, and giant cells were seen, up to 23 days after the rash. She began to improve after the immunoglobulin treatment, and her antibody titre rose to $1 / 32$, but because of a recurrence of fever and the persistence of virus in the secretions three further doses of $1500 \mathrm{mg}$ of immunoglobulin were given on the 26th, 28th, and 29th days of the illness, after which the measles antibody titre reached a level of $1 / 64$. Thereafter she improved rapidly, virus could no longer be cultured or shown in cells of her nasopharyngeal secretions, and she resumed her antileukaemic treatment.

\section{Case 2}

This boy, born in 1967, developed measles encephalopathy. In December 1972 he was admitted to hospital with acute lymphoblastic leukaemia. He.was treated on the Medical Research Council UKALL II schedule of cytotoxic drugs and with radiotherapy. The standard doses of cytotoxic drugs had to be reduced many times because of marrow hypoplasia, and he suffered profuse eruptions of herpes simplex virus infection round his mouth on nine occasions and herpes zoster eruptions on his trunk on two occasions during his two and a half years of treatment.

During the 114th week of treatment he was exposed to measles and two days later was given pooled immunoglobulin $750 \mathrm{mg}(33 \mathrm{mg} / \mathrm{kg}$ body weight). Ten days after contact his sister developed measles but the boy remained well until 19 days after the first contact, when he developed a mild respiratory infection without any rash. This cleared up over the next 10 days, but his behaviour began to change, with refusal to attend school, which he usually enjoyed. He remained emotionally labile, and nine weeks after contact he suddenly developed focal motor seizures affecting his left leg; these lasted under a minute but recurred several times a day. The frequency of these seizures increased and he was readmitted two days after their onset. Thereafter he deteriorated rapidly, with increasing drowsiness, the appearance of long tract signs, slurring of speech, more prolonged focal and generalised seizures, confusion, coma, and death eight days after admission.

Investigations showed the cerebrospinal fluid to be acellular with a protein content of $0.29 \mathrm{~g} / 1$; no virus was isolated from two specimen and measles antibody was not looked for. There was no measles antibody in the serum and the antibody titre to herpes virus hominis was $1 / 20$. A carotid angiogram and a brain scan showed no abnormality. The electroencephalogram was diffusely slow with higher voltages in the left hemisphere.

\section{NECROPSY}

Gross examination of the lungs showed areas of collapse, and microscopic examination showed this to be associated with acute bronchopneumonia. No giant cells or inclusion bodies of measles were seen in the sections examined. Cytomegalovirus was identified on culture. The brain weighed $1270 \mathrm{~g}$, and nothing abnormal was

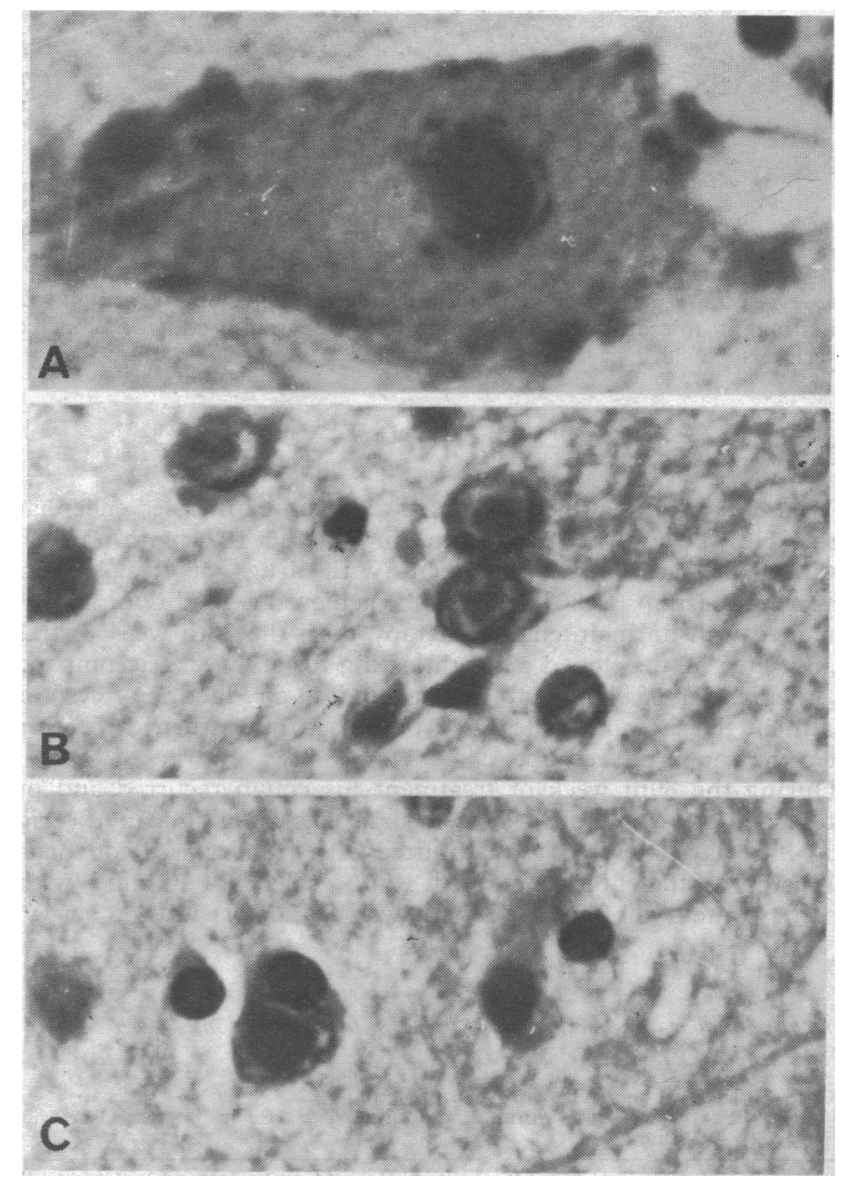

FIG 2-(a) Intranuclear inclusion body in neurone. (Haematoxylin and eosin. $\times 2500$.) (b) Intranuclear inclusion in astrocyte. (Haematoxylin and eosin. $\because 1600$.) (c) Intracytoplasmic inclusion in astrocyte. (Haematoxylin and eosin. $\because 1600$.) 
seen on external examination or on scrutiny of multiple coronal sections after fixation. Histological examination (fig 2) showed numerous intranuclear and cytoplasmic inclusion bodies within astrocytes and degenerate neurons of the parieto-occipital areas, the basal ganglia, and brain stem. In these areas there was extensive neuronal loss with astrocytic and microglial proliferation. There was spongy degeneration in the parieto-occipital areas and mild diffuse fibrillary gliosis in the white matter of the cerebral hemispheres. No perivascular inflammation was seen in any of the sections examined, there was no evidence of demyelination, and some areas of the cortex showed no abnormality. No virus was cultured from brain samples.

Electron microscopy (fig 3) showed that the eosinophilic inclusion bodies seen on light microscopy were microtubular structures. On higher magnification the diameter of these tubules was seen to be of the order of 180 ångströms and they appeared identical to the nucleocapsids of paramyxoviruses. Paraffin sections from the right parietooccipital cortex and the midbrain were stained by indirect immunofluorescence, and these showed many neurons and glial cells with bright fluorescence in their nuclei and cytoplasm when treated with human subacutc sclerosing panencephalitis (SSPE) serum and with guinea-pig anti-measles serum but no fluorescence with rabbit antiherpes serum or with human and guinea-pig serum devoid of measles antibody.

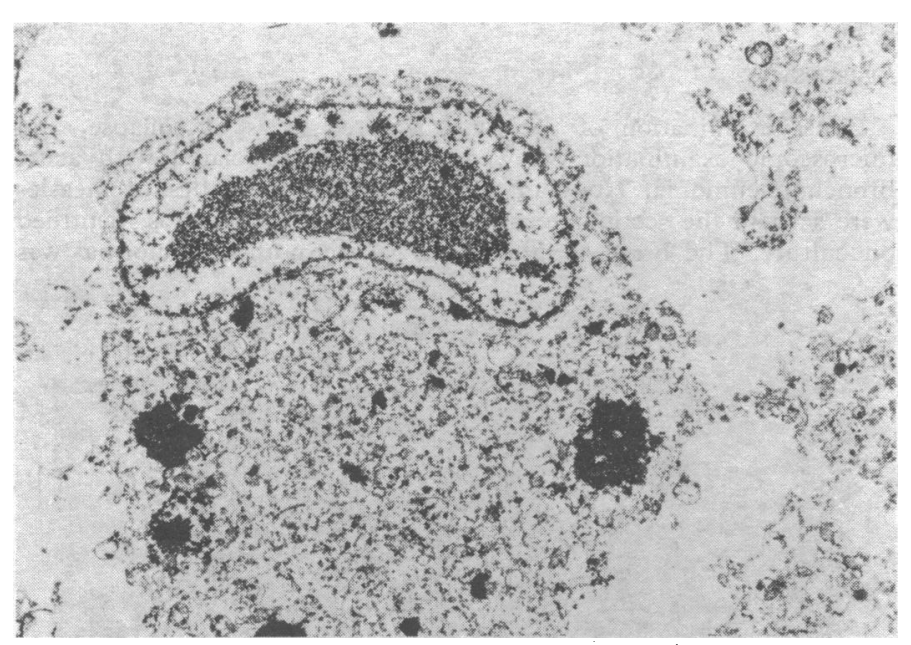

FIG 3-Electron micrograph showing intranuclear inclusion body in glial cell consisting of microtubular-like structure. (Deparaffinised, formalin-fixed material. $\times 5688$.)

\section{Case 3}

This boy, born in 1966, developed a presumed measles encephalopathy. He was admitted to hospital in October 1974 with unusually advanced leukaemia. On treatment with drugs of the American Leukaemia Group B 6801 schedule he achieved a good remission and remained well on maintenance therapy until the 28 th week of treatment, when he developed a cough lasting for six weeks accompanied by a depression of blood counts that required a reduction of cytotoxic treatment. He became listless and depressed but returned to normal when the cough cleared up.

During the 39th week of treatment his cough recurred and persisted, and $x$-ray pictures showed signs of pneumonia in the right lung. Ten days later he was readmitted with a generalised convulsion. His cerebrospinal fluid contained $4 \times 10^{9}$ cells $/ 1\left(4000 / \mathrm{mm}^{3}\right)$ with a protein content of $0.38 \mathrm{~g} / \mathrm{l}$. There was no history of contact with measles and he did not develop a rash. During week 40 his serum measles antibody titre was less than $1 / 10$, but during week 42 it rose to $1 / 640$, and during week 45 it reached $1 / 1280$.

From the time of the convulsion this boy never returned to normal. There were frequent dystonic movements of the arms, and he became clumsy. His mental state deteriorated steadily with confusion, irritability, aggression, emotional lability, withdrawal, and two more generalised seizures in weeks 55 and 56. Examination of the cerebrospinal fluid during week 45 showed that it contained no cells, but the measles complement-fixing antibody titre was $1 / 80$. His electroencephalogram was grossly abnormal with delta activity and generalised epileptic discharges. During week 57 the fluid showed signs of meningeal leukaemia. He died during week 59. Permission for necropsy was not given.

\section{Discussion}

The important clinical features of the three cases are shown in the table. All three patients were in satisfactory remission from acute lymphoblastic leukaemia when they were infected with measles. In case 1 the virus was shown repeatedly in nasopharyngeal secretions, in case 2 it was seen on electron microscopy of the brain, and in case 3, although the virus itself was never identified, there was a striking rise in measles antibody level in the serum at a time when there was clinical and radiological evidence of pneumonia, followed by clinical signs of encephalopathy and the appearance of measles complementfixing antibody in the cerebrospinal fluid. There were recognised exposures to measles in the first two patients, but standard doses of pooled immunoglobulin failed to protect them, and only one of the three children developed any rash.

While the altered immunological responses to measles in our three cases probably resulted from the immunosuppressive effects of the cytotoxic drugs and radiotherapy that they had been given, the co-existence of other virus infections, most obvious in the recurrent herpes in case 2 , may have contributed. Mangi et $a l^{5}$ have shown that depression of cell-mediated immunity may result from antigenic competition.

As long ago as 1959 measles giant-cell pneumonia was described in four children suffering from leukaemia ${ }^{2}$; these patients did develop rashes but no measles antibody was found, and the virus was identified in their nasopharyngeal secretions for up to a month. The authors ascribed the immunosuppression to the leukaemia alone, but all four children had been treated with methotrexate. Fatal measles giant-cell pneumonia has been recorded in a nephrotic child treated with large doses of cyclophosphamide, ${ }^{6}$ and a group of three children in leukaemic remission, who all died within six months of measles infection, has been described ${ }^{3}$; one of these patients developed giant-cell pneumonia, another the picture of SSPE with high measles antibody titres, and the third both measles pneumonia and encephalopathy without antibody.

Our first patient developed giant-cell pneumonia with prolonged excretion of measles virus in the nasopharyngeal secretions. In a recently studied group of children who developed measles it was found that measles-infected giant cells were not usually excreted for more than three days and excretion had ceased by six days after the appearance of the rash. ${ }^{7}$ Prolonged excretion of virus has been described in children on immunosuppressive treatment ${ }^{2}$ and in malnourished Kenyan children ${ }^{8}$ and may be an unfavourable prognostic sign in both of these groups.

Clinical and laboratory findings in atypical measles infections

\begin{tabular}{|c|c|c|c|c|c|c|c|c|c|}
\hline \multirow{2}{*}{$\begin{array}{l}\text { Case } \\
\text { No }\end{array}$} & \multirow{2}{*}{$\begin{array}{c}\text { Interval between } \\
\text { exposure and } \\
\text { illness }\end{array}$} & \multirow{2}{*}{$\begin{array}{l}\text { Dose of pooled } \\
\text { immunoglobulin }\end{array}$} & \multirow{2}{*}{ Rash } & \multirow{2}{*}{ Pneumonia } & \multirow{2}{*}{ Encephalopathy } & \multicolumn{2}{|c|}{ Antibody } & \multirow{2}{*}{$\begin{array}{c}\text { Measles } \\
\text { virus }\end{array}$} & \multirow{2}{*}{ Outcome } \\
\hline & & & & & & Serum & $\mathrm{CSF}$ & & \\
\hline $\begin{array}{l}1 \\
2\end{array}$ & $\begin{array}{l}23 \text { days } \\
9 \text { or } 19 \text { days }\end{array}$ & $\begin{array}{l}45 \mathrm{mg} / \mathrm{kg} \\
33 \mathrm{mg} / \mathrm{kg}\end{array}$ & $\begin{array}{l}\text { For } 2 \text { weeks } \\
\text { None }\end{array}$ & $\begin{array}{l}\text { Giant cell } \\
\text { Mild }\end{array}$ & $\begin{array}{l}\text { None } \\
\text { Fatal }\end{array}$ & $\begin{array}{l}1 / 64 \\
0\end{array}$ & $\begin{array}{l}\text { Not done } \\
\text { Not done }\end{array}$ & $\begin{array}{l}\text { For } 23 \text { days } \\
\text { Seen on } \\
\text { electron }\end{array}$ & $\begin{array}{l}\text { Lived } \\
\text { Died }\end{array}$ \\
\hline 3 & Unknown & Not given & None & Mild & Fatal & $1 / 1280$ & $1 / 80$ & $\begin{array}{l}\text { microscopy } \\
\text { Not found }\end{array}$ & Died \\
\hline
\end{tabular}


The appearance of abnormal neurological signs in children with leukaemia in haematological remission may be due to the post-irradiation syndrome" or methotrexate toxicity ${ }^{10}$ in the early months of treatment and meningeal leukaemia, haemorrhage, or infection of the central nervous system at any stage. The histological appearance of the brain in our case of measles encephalopathy resembled neither the appearances in acute measles encephalitis nor those in SSPE. There was a surprising absence of perivascular inflammatory cells, and the predominating features were focal neuronal loss, spongy changes, and gliosis, with many nuclear and cytoplasmic inclusion bodies in some areas and none in others. Similar appearances have been described previously." Hence possibly some of the cases of encephalopathy that have been recorded in children with leukaemia may have resulted from measles infection without obvious inclusion bodies being seen in the brains of those who reached necropsy. ${ }^{10}{ }^{13}$ Lesions produced in the brains of monkeys by intracerebral and intranasal inoculation with different viruses can be modified by concurrent administration of cyclophosphamide ${ }^{14}$; animals given immunosuppressive therapy showed not only increased invasiveness of the viruses but also the replacement of the expected cerebral inflammatory changes by a degenerative process causing neuronal necrosis and spongy degeneration.

\section{Conclusions and recommendations}

In children on immunosuppressive treatment primary measles infection may present with very atypical clinical pictures. The incubation period may be prolonged, there may be no rash or a rash that lasts for weeks, and the illness may be mild or very severe. Commonly used doses of pooled immunoglobulin may fail to protect against measles infection and may further confuse the diagnosis by modifying the illness. Two doses of $1500 \mathrm{mg}$ at an interval of 48 hours are recommended by the Public Health Laboratory Service for children over three years of age on immunosuppressive treatment.

In the giant-cell pneumonia resulting from measles infection the virus may persist in nasophrayngeal secretions for three weeks or more. In either giant-cell pneumonia or encephalpathy after measles infection antibody formation in the blood is unpredictable, and may be low or absent even when measles virus is present in profusion in the lungs or brain. Nevertheless, measles antibodies should be sought when leukaemia is first diagnosed and repeatedly in serum or cerebrospinal fluid in any unusual respiratory infection or encephalopathy during the course of cytotoxic treatment.

The histological picture resulting from invasion of the brain by measles virus resembles neither the acute inflammatory appearances seen in post-measles encephalitis nor those of SSPE. An appropriate term might be "immunosuppressive measles encephalopathy."

Repeated large doses of pooled immunoglobulin may have some beneficial effect in measles giant-cell pneumonia, but since no treatment is effective in measles encephalopathy every effort should be made to prevent measles infection. Nonimmune siblings should be immunised and segregated from the patient for a fortnight.

We thank Dr A $\mathrm{H}$ Tomlinson for carrying out the immunofluorescence studies on the brain in case 2. We thank Miss Maureen McKeown for secretarial help.

Requests for reprints should be addressed to Dr T C Noble.

\section{References}

${ }^{1}$ Levine, A S, et al, Seminars in Hematology, 1974, 11, 141.

2 Mitus, A, et al, New England fournal of Medicine, 1959, 261, 882.

${ }^{3}$ Brietfeld, V, et al, Laboratory Investigation, 1973, 28, 279.

- Sluga, E, et al, Acta Neuropathologica, 1975, suppl No 6, p 267.

${ }^{5}$ Mangi, R J, et al, New England fournal of Medicine, 1974, 291, 1149.

6 Meadows, S R, Weller, R O, and Archibald, R W R, Lancet, 1969, 2, 876.

7 McQuillin, J, et al, Archives of Disease in Childhood, in press.

${ }^{8}$ Scheifell, D W, and Forbes, C E, Paediatrics, 1972, 50, 867.

${ }_{9}$ Garwicz, S, et al, Acta Paediatrica Scandinavica, 1975, 64, 399.

${ }^{10} \mathrm{Kay}, \mathrm{H} \mathrm{E} \mathrm{M,} \mathrm{et} \mathrm{al,} \mathrm{Archives} \mathrm{of} \mathrm{Disease} \mathrm{in} \mathrm{Childhood,} \mathrm{1972,} \mathrm{47,} 344$.

${ }^{11}$ Hendin, B, et al, Cancer, 1974, 33, 468.

12 Price, R A, and Jamieson, P A, Cancer, 1975, 35, 306.

13 Rubinstein, L J, et al, Cancer, 1975, 35, 291.

14 Zlotnik, I, et al, British Fournal of Experimental Pathology, 1970, 51, 434.

\title{
HLA-linked genes and islet-cell antibodies in diabetes mellitus
}

\author{
R LENDRUM, GEOFFREY WALKER, A G CUDWORTH, J C WOODROW， D R GAMBLE
}

British Medical fournal, 1976, 1, 1565-1567

\section{Summary}

In a random series of 139 insulin-dependent diabetics aged 30 or under at the onset of disease islet-cell antibody (ICA) was detected in 33 cases $\left(24^{\circ}{ }_{0}\right)$. In 27 patients who had had diabetes for less than one year $16\left(59^{\prime}{ }_{0}^{\prime}\right)$ had

Gastroenterological Department, St Mary's Hospital, London W2 R LENDRUM, MA, MRCP, research fellow GEOFFREY WALKER, MD, FRCP, consultant physician

Department of Medicine, University of Liverpool, Liverpool

A G CUDWORTH, MD, MRCP, lecturer in medicine

$\mathrm{J} C$ WOODROW, MD, FRCP, reader in medicine

Public Health Laboratory, West Park Hospital, Epsom

D R GAMBLE, FRCPATH, DIPBACT, director
ICA. Only one out of 51 patients with maturity onset diabetes who were not dependent on insulin were positive for ICA. Four out of 19 patients with late onset insulindependent diabetes had ICA.

There was no association between the presence of ICA and any particular HLA phenotype. Within families containing two or more HLA haploidentical siblings with juvenile onset diabetes ICA was a variable finding both in its occurrence and in its relation to the duration of disease.

A possible mode of action for the HLA-linked gene may be to permit a rapid immunological destructive process, possibly associated with viral infection.

\section{Introduction}

Recent studies have produced evidence that susceptibility to juvenile onset or insulin-dependent diabetes is associated with particular HLA phenotypes, ${ }^{1-3}$ there being a twofold to three- 